\title{
Penerapan Kombinasi Pijat Punggung Dan Dzikir Terhadap Tingkat Stres Pada Penderita Hipertensi Di Desa Seturi Kabupaten Batang
}

\author{
Riska Yustianika ${ }^{1 *}$, Aisyah Dzil Kamalah² \\ 1,2Program StudiDiploma Tiga KeperawatanFalkutas Ilmu KesehatanUniversitas Muhammadiyah \\ Pekajangan Pekalongan, Indonesia \\ *email: yustianika86@gmail.com
}

\begin{abstract}
Hipertension is an increase of systolic blood pressure above $140 \mathrm{mmHg}$ and diastolic above $90 \mathrm{mmHg}$. The patients get dizziness, anxiety, stress, restlessness, weakness, and worry about their health. The purpose of this case study was to determine the application of a combination of back massage and dhikr to stress levels in hypertension sufferers in Seturi Village, Batang Regency. The method used in this paper was a case study with the subject of two axienty clients. The focus of the intervention was providing non-pharmacological therapy, relaxcation, back massage and dhikr for 3 visits to the client's home. The result of the case studies on these two client's showed a change in the level of stress on hypertension reduced in client I from TD : $160 / 100 \mathrm{mmHg}$ down to $140 / 90 \mathrm{mmHg}$, PSS-10 : Score 14 (moderate stress) to 0 (no stress), moderate client II from TD : 170/100 $\mathrm{mmHg}$ down to $140 / 90 \mathrm{mmHg}$, PSS-10 : Score 26 (moderate stress) to 0 (no stress). Therefore, it can be concluded that there is an effect of back massage therapy and dhikr on stress stress levels in patients with hypertension. There is also stress levels in patiens with hypertension.
\end{abstract}

Keywords : Dhikir; Clients With Hipertension; Back Massage And Stress

\begin{abstract}
Abstrak
Hipertensi adalah peningkatan tekanan darah sistolik berada diatas $140 \mathrm{mmHg}$ dan diastolik diatas $90 \mathrm{mmHg}$. Keluhan yang dirasakan adalah pusing, cemas, stress, gelisah, lemas, dan khawatir terhadap penyakitnya. Tujuan studi kasus ini adalah untuk mengetahui penerapan kombinasi pijat punggung dan dzikir terhadap tingkat stress pada penderita hipertensi di Desa Seturi Kabupaten Batang. Metode studi kasus ini adalah studi kasusdengan subyek dua klien ansietas. Fokus intervensi berupa pemberian terapi non farmakologi relaksasi pijat punggung dan dzikir selama 3 kali kunjungan kerumah klien. Hasil studi kasus pada kedua klien ini menunjukkan adanya perubahan tingkat stress terhadap hipertensipada kedua klien ini menunjukkan adanya perubahan tingkat stress terhadap hipertensi berkurang pada klien I dari TD : $160 / 100 \mathrm{mmHg}$ turun menjadi $140 / 90 \mathrm{mmHg}$, PSS-10 : Skore 14 (stress sedang) menjadi 0 (tidak stress), sedang klien II dari TD : $170 / 100 \mathrm{mmHg}$ turun menjadi $140 / 90$ mmHg, PSS-10 : Skore 26 (stress sedang) menjadi 0 (tidak stress). Kesimpulan : Ada pengaruh terapi pijat punggung dan dzikir terhadap tingkat stress pada penderita hipertensi. Berdasarkan hasil penerapan tersebut maka disarankan peran perawatdapat memberikan terapi pijat punggung dan dzikir untuk menurunkan tingkat stress pada penderita hipertensi.
\end{abstract}

Kata kunci : Dzikir; Klien Dengan Hipertensi; Pijat Punggung Dan Stress.

\section{Pendahuluan}

Badan kesehatan dunia WHO tahun 2015 menunjukan 1,3 milyar penduduk di dunia menderita hipertensi, artinya hanya 1 dari 3 orang di dunia terdiagnosis hipertensi, hanya $36,8 \%$ diantaranya yang meminum obat hipertensi. Prevalensi hipertensi diprediksi akan meningkat pada setiap tahunnya, diperkirakan pada tahun 2025 akan ada 1,5 milyar orang yang terkena hipertensi. Penyakit hipertensi pada 


\section{Prosiding Seminar Nasional Kesehatan $\mid 2021$ Lembaga Penelitian dan Pengabdian Masyarakat Universitas Muhammadiyah Pekajangan Pekalongan}

tahun 2017, telah mengakibatkan kematian 9,4 juta jiwa pada setiap tahunnya (Kemenkes RI, 2017).Prevalensi hipertensi di Indonesia pada lansia berumur 55-67 tahun sebesar 53,7\%, usia 65-74 tahun sebesar 73,5\%. Pada tahun 2016 tercatat bahwa sebanyak $20,16 \%$ penderita hipertensi diatas 18 tahun, berdasarkan dari jenis kelamin hipertensi lebih banyak diderita oleh perempuan sebesar $11,85 \%$, sedangkan pada laki-laki sebesar 11,16\% (Profil Kesehatan Jateng,2016). Penderita Hipertensi di Jawa Tengah pada tahun 2018 sebanyak 8,2\%, penduduk yang mengkonsumsi obat antihipertensi sebanyak 8,6\% (Riskesdas,2018). Provinsi Jawa Tengah 2015 tercatat dari hasil pengukuran tekanan darah, sebanyak 344.033 orang atau $17,74 \%$ dinyatakan hipertensi. Berdasarkan jenis kelamin, persentase hipertensi pada kelompok laki-laki sebesar 20,88\%, lebih tinggi dibanding pada kelompok perempuan yaitu $16,28 \%$ (Provinsi Dinas Kesehatan Jateng,2015). Di Kabupaten Batang 2017 tercatat sebanyak 255.064 orang $(49,45 \%)$ dari jumlah penduduk $\geq 18$ tahun (515.836 jiwa) dan ditemukan sebanyak 18.819 orang $(7,38 \%)$ terdeteksi memiliki tekanan darah tinggi dan menurun bila dibandingkan dengan tahun 2016 yaitu 57,69\% penduduk usia $\geq 18$ tahun yang dilakukan pengukuran tekanan darah dan 8,94\% terdeteksi memiliki tekanan darah tinggi (Batang, Dinas Kesehatan 2017).

Hipertensi disebabkan oleh usia, jenis kelamin, keturun (genetik), obesitas, konsumsi alkohol, kafein berlebihan, konsumsi garam berlebih, stress, dan keseimbangan hormonal (Sari, 2017). Tanda dan gejala hipertensi menurut Herlambang (2013) sebagian besar penderita, hipertensi tidak menimbulkan gejala meskipun secara tidak sengaja beberapa gejala terjadi bersamaan dan dipercaya berhubungan dengan tekanan darah tinggi (padahal sesungguhnya tidak), tanda gejala yang dimaksud dari hipertensi adalah sakit kepala, pendarahan dari hidung, pusing, wajah kemerahan, dan kelelahan yang bisa saja terjadi baik pada penderita hipertensi, maupun pada seseorang tekanan darah yang normal. Akibat dari hipertensi menurut Herlambang (2013) hipertensi dapat merusak organ dalam tubuh meliputi otak yang dapat menyebabkan stroke, mata yang dapat mengakibatkan retinopati hipertensi dan dapat menimbulkan kebutaan, jantung yang dapat menyebabkan penyakit jantung koroner (termasuk infark) gagal jantung, ginjal yang dapat menyebabkan penyakit ginjal kronik dan gagal ginjal terminal, selain itu hipertensi juga dapat mengakibatkan stress pada penderitanya.

Menurut South (2014) stress pada penderita hipertensi disebabkan pada saat seseorang mengalami stress, hormon adrenalin akan dilepaskan dan kemudian akan meningkatkan tekanan darah melalui kontraksi arteri (vasokontriksi) dan peningkatan denyut jantung, apabila stress berlanjut, tekanan darah akan tetap tinggi sehingga orang tersebut akan mengalami hipertensi. Tanda dan gejala stress pada penderita hipertensi menurut Sari (2017) mengatakan bahwa bagi beberapa orang, stress juga dapat meningkatkan nafsu makan dan kebiasaan merokok sehingga semakin memperburuk keadaan hipertensi, serta memicu penyakit degeneratif lain seperti penyakit jantung dan stroke. Akibat dari stress pada hipertensi menurut Ramdani et al(2017) mengatakan bahwa reaksi tubuh yang terjadi mengakibat stress meliputi napas pendek, jantung berdebar-debar dan keringat dingin dan stress tidak 


\section{Prosiding Seminar Nasional Kesehatan $\mid 2021$ Lembaga Penelitian dan Pengabdian Masyarakat Universitas Muhammadiyah Pekajangan Pekalongan}

memandang usia, stress dapat digolongkan menjadi tiga bagian yaitu stress ringan, stress sedang dan stress berat.

Intervensi keperawatan yang digunakan untuk menurunkan tingkat stress dan tekanan darah pada penderita hipertensi salah satunya adalah dengan pijat punggung dan dzikir,seperti hasil penelitian Haryono (2016) menunjukkan kelompok intervensi kombinasi pijat punggung dan dzikir mengalami penurunan tingkat stress dan tekanan darah, dibandingkan dengan kelompok yang tidak dilakukan pijat punggung dan terapi dzikir.

Menurut $\mathrm{Hu}$ et al (2015) mengatakan bahwa stress psikologis dikaitkan dengan risiko yang lebih besar terjadi hipertensi dibandingkan dengan orang yang yang tidak mengalami stress psikologis yang bisa mencapai 9\%. Stres adalah keadaan internal yang dapat diakibatkan oleh tuntutan fisik dari tubuh dan kondisi lingkungan dan sosial yang dinilai pontensial membahayakan, tidak terkendala atau melebihi kemampuan individu untuk mengatasinya (Lazarus dan Folman dan Rika, 2014).Stres dapat memicu timbulnya hipertensi melalui aktivasi sistem saraf simpatis yang mengakibatkan naiknya tekanan darah secara intermiten (tidak menentu) (Andria, 2013). Pada saat seseorang mengalami stres, hormon adrenalin akan dilepaskan dan kemudian akan meningkatkan tekanan darah melalui kontraksi arteri (vasokontriksi) dan peningkatan denyut jantung, dan apabila stres berlanjut, tekanan darah akan tetap tinggi sehingga orang tersebut akan mengalami hipertensi (South, 2014). Tingginya insidensi stres di Indonesia juga merupakan alasan mengapa stres harus diprioritaskan penanganannya sebab pada tahun 2008 tercatat sekitar $10 \%$ dari total penduduk Indonesia mengalami gangguan mental atau stres, tingginya tingkat stres ini umumnya diakibatkan oleh tekanan ekonomi atau kemiskinan, Departemen statistika menyatakan bahwa 31 juta jiwa atau $13,33 \%$ penduduk Indonesia berada pada garis kemiskinan dengan pengeluaran perbulan dibawah Rp 211.726,00 (Depkes, Handayani, 2012). Rendahnya pendapatan masyarakat yang hanya cukup untuk menyambung hidup tentu menimbulkan tekanan tersendiri. Intervensi keperawatan yang digunakan untuk menurunkan tingkat stress dan tekanan darah pada penderita hipertensi salah satunya adalah dengan pijat punggung dan dzikir,seperti hasil penelitian Haryono (2016) menunjukkan kelompok intervensi kombinasi pijat punggung dan dzikir mengalami penurunan tingkat stress dan tekanan darah, dibandingkan dengan kelompok yang tidak dilakukan pijat punggung dan terapi dzikir.

Pijat punggung adalah gerakan usapan, baik dilakukan dengan telapak tangan atau bantalan jari tangan.Gerakan ini dapat dilakukan dengan ringan ataupun dengan sedikit penekanan, gerakan ringan biasanya digunakan untuk meratakan minyak pijat, pengenakan gerakan (sebagai gerakan pemulaan) maupunmenenangkan kembali jaringan otot yang telah dirangsang dengan gerak-gerakan lainnya dan pijat punggung dapatmengurangi tekanan darah sistolik dan diastolik.Pemberian pijat memberikan efek secara langsung yaitu rasa rileks. Hal ini terjadi karena pijat punggung akan membuat pembuluh darah dilatsai, otot akan relaksasi, serta kondisi psikologi akan lebih baik karena peningkatan endorphin dan serotonin di otak (Nugraha, Fatimah dan Kurniawan, 2017). Intervensi keperawatan yang digunakan adalah dengan cara spiritual, salah satunya adalah dengan terapi dzikir. 


\section{Prosiding Seminar Nasional Kesehatan $\mathbf{2 0 2 1}$ Lembaga Penelitian dan Pengabdian Masyarakat Universitas Muhammadiyah Pekajangan Pekalongan}

Dzikir adalah bagian paling substansial dalam ibadah, bahkan dapat dikatakan sebagai ruh ibadah (Said, 2012). Terapi zidkir dapat dijadikan sebagai metode alternativ yang baik untuk menangani stress (Ridha, dkk. 2017). Respon relaksasi yang melibat keyakinan yang dianut akan mempercepat terjadinya keaadaan relaks atau dengan kata lain kombinasi respon relaksasi yang melibatakan keyakinan akan melipat gandakan manfaat yang dapat dari respon relaksasi semakin kuat keyakinan seseorang berpadu dengan respon relaksasi maka semakin besar pula efek yang di dapat (Nasriti, 2015). Keadaan releks akan membuat tubuh melalui otak memproduksi endorphin yang berfungsi sebagai analgesik alami tubuh dan dapat mengurangi keluhan-keluhan fisik serta keadaan rileks membuat tubuh akan mengaktifkan sistem saraf parasimpatik yang berfungsi untuk menurunkan detak jantung, laju pernafasan dan tekanan darah (Poppen, 1998 dalam Sulistyarini, 2013). Hal ini juga tertuang dalam QS. Ar- Ra“d ayat 28 yang artinya: "Yaitu orang-orang yang beriman dan hati mereka menjadi tentram dengan mengingat Allah, ingatlah, hanya dengan mengingat Allah-lah hati menjadi tentram" keuntungan dari relaksasi dzikir selain mendapatkan manfaat dari relaksasi, juga mendapatkan manfaat dari penggunaan keyakinan seperti menambah keimanan, dan kemungkinan akan mendapatkan pengalaman-pengalaman transendensi (Sudiarto, dkk, 2015). Tujuan penulis dari studi kasus ini adalah penerapan kombinasi pijat punggung dan dzikir terhadap tingkat stress pada penderita hipertensi, untuk menurunkan tingkat stress dan tekanan darah.

\section{Metode}

Metode pengumpulan data yang digunakan penulis dalam studi kasus ini yaitu dengan fokus pada pemilihan subyek yang akan diteliti, mengumpulkan data secara konsisten, menjaga validasi penulisan, serta memecahkan suatu masalah dengan metode pengumpulan data wawancara dan observasi. Penulis mencari dua klien sesuai dengan subyek studi kasus yaitu orang yang mempunyai riwayat tingkat stress terhadap hipertensi, penulis memberikan lembaran persetujuan informed consent kepada klien I dan klien II, penulisan melakukan pengkajian pada klien I dan klien II, penulisan membuat diagnosa dan intervensi pada klien I dan klien II, penulis melakukan implementasi dan evaluasi pada klien I dan klien II.

\section{Hasil dan Pembahasan Pengkajian}

Pada hasil data yang ditemukan pada saat pengkajian Ny.N dan Ny.A dengan hipertensi meliputi tekanan darah tinggi, pusing, cemas, stress, gelisah lemas dan khawatir terhadap penyakitnya. Hal ini disebabkan karena klien hipertensi sedang dan tingkat stress sedang dengan hasil pemeriksaan pada Ny.N TD : $160 / 100 \mathrm{mmHg}$, S ; 36,5 C, N : 83x/menit, Rr: 22x/menit, PSS-10 skore 14 (stress sedang) dan Ny.A dengan hasil pemeriksaan TD : $170 / 100 \mathrm{mmHg}, \mathrm{N}: 83 \mathrm{x} /$ menit, $\mathrm{S}: 36 \mathrm{C}, \mathrm{RR}$ : $22 x /$ menit, PSS-10 skore 26 (stress sedang). Disamping itu tidak ditemukan data obesitas tetapi dapat timbul pada setiap orang.

\section{Diagnosa Keperawatan}

Berdasarkan hasil pengkajian yang sudah dilakukan kepada klien I dan klien II, penulis merumuskan diagnosa keperawatan Ansietas. Pada hasil pengkajian klien I dan 


\section{Prosiding Seminar Nasional Kesehatan Lembaga Penelitian dan Pengabdian Masyarakat Universitas Muhammadiyah Pekajangan Pekalongan}

klien II ditemukan data subyektif : Klien I mengatakan pusing, cemas, stress, gelisah,lemas, dan khawatir terhadap penyakitnya, data obyektif : Klien tampak tegang, klien tampak berkeringat dingin, klien tampak sedih, TD : 160/100 $\mathrm{mmHg}, \mathrm{S}$ : 36,5 C, N : 83x/menit, Rr :22x/menit, PSS-10 skore 14 (Stress sedang) dan subyektif : Klien II mengatakan pusing, cemas, stress, gelisah, lemas, dan khawatir terhadap penyakitnya, data obyektif : Klien tampak tegang, klien tampak berkeringat dingin, klien tampak sedih, klien tampak ada lingkar hitam dibahwa mata, TD : 160/100 mmHg, S : 36,5 C, N : 83x/menit, Rr :22x/menit, PSS-10 skore 26 (Stress sedang).

\section{Perencanaan}

Penulis merumuskan intervensi keperawatan berdasarkan diagnosa yang muncul pada klien I dan klien II sama yaitu Ansietas. Tujuan Asuhan Keperawatan yang diharapkan adalah setelah dilakukan tindakkan selama 3 kali kunjungan diharapkan ansietas berkurang dengan : 1 . Kognitif, klien mampu : a. Mengenal pengertian, penyebab, tanda gejala, akibat, dan proses terjadinya ansietas. b. Mengetahui cara mengatasi ansietas. 2. Psikomotor, klien mampu mengatasi ansietas dengan : a. Melakukan latihan relaksasi terapi pijat punggung dan dzikir. 3. Afektif, klien mampu : a. Merasakan manfaat dari latihan yang dilakukan. b. Membedakan perasaan sebelum dan sesudah latihan.

Rencana Keperawatan yang disusun untuk Diagnosa Ansietas adalah : 1. Monitor TTV. 2. Kaji tanda-tanda dan gejala ansietas dan kemampuan klien dalam mengurangi ansietas. 3. Menjelaskan proses terjadinya ansietas. 4. Ajarkan latih cara mengatasi ansietas dengan non-farmakologi relaksasi terapi pijat punggung dan dzikir. 5. Membantu klien untuk melakukan latihan sesuai dengan jadwal kegiatan.

\section{Implementasi}

Implementasi yang sudah penulis lakukan pada klien I dan klien II adalah sesuai dengan rencana keperawatan, klien I dan klien II koperatif. Pijat punggung adalah gerakan usapan, baik dilakukan dengan telapak tangan atau bantalan jari tangan.Gerakan pijat dapat dilakukan dengan ringan ataupun dengan sedikit penekanan. Gerakan ringan biasanya dapat digunakan untuk meratakan minyak pijat, pengenakan gerakan (sebagai gerakan pemulaan) maupun menenangkan kembali jaringan otot yang telah dirangsang dengan gerakan-gerakan lainnya dan pijat punggung dapat mengurangi tekanan darah sistolik dan diastolik. Pemberian pijat memberikan efek secara langsung yaitu rasa rileks. Hal ini dapat terjadi karena pijat punggung akan membuat pembuluh darah dilatsai, otot akan relaksasi, serta kondisi psikologi akan lebih baik karena peningkatan endorphin dan serotonin di otak Kurniawan (2017).

Dzikir dari segi bahasa (Lughatan) atau etimologi adalah mengingat, sedangkan secara istilah adalah membasahi lidah dengan ucapan-ucapan pujian kepada Allah. Menurut Syaikh Ahmad Fathani menjelaskan, bahwa dzikir pada mulanya diartikan sebagai " bersih" (Asshafa), wadahnya adalah menyempurnakan (Al-Wafa), dan syaratnya adalah hadir dihadiratnya (Hudhur), harapannya adalah lahirnya amal shaleh, dan hasiatnya adalah terbukanya tirai rahasia atas kedekatan seorang hamba kepada Allah SWT Fatoni (2020). 


\section{Prosiding Seminar Nasional Kesehatan $\mid 2021$ Lembaga Penelitian dan Pengabdian Masyarakat Universitas Muhammadiyah Pekajangan Pekalongan}

Dibuktikan dalam jurnal Rudi Haryono (2016) menunjukkan nilai rata-rata penurunan skala stress yang terjadi adalah sebanyak 4,27 poin. Klien I dengan usia 55 tahun memasuki usia lansia, sehingga klien I ketika dijelaskan harus berulang-ulang karena lambat dalam menanggapi. Maryam (2011) usia memasuki lansia menyebabkan mereka sulit untuk menanggapi secara cepat, sulit dipahami, sulit dalam berinteraksi, adanya penurunan fungsi sistem sensorik, maka akan terjadi pula penurunan kemampuan untuk menerima, memproses dan merespon stimulus sehingga terkadang akan muncul aksi atau reaksi yang berbeda dari stimulus yang ada, sedangkan pada klien II dengan usia 37 tahun memasuki usia dewasa, sehingga klien II ketika dijelaskan langsung dapat menanggapi dengan. Yudrik (2017) usia dewasa akhir ini terjadi penurunan kekuatan fisik, berubahnya fisik, juga psikis pada seseorang dan penurunan daya ingat namun masih bisa menanggapi secara langsung.

\section{Evaluasi}

Evaluasi dari tindakan keperawatan yang penulis lakukan pada kedua klien tersebut menunjukkan hasil yang sama, pada klien I dari TD : 160/100 mmHg turun menjadi 140/90 mmHg, PSS-10 : Skore 14 (stress sedang) menjadi PSS-10 : Skore 0 (tidak stress) sedang klien II dari TD : 170/100 mmHg turun menjadi 140/90 mmHg, PSS-10 : Skore 26 (stress sedang) menjadi PSS-10 : Skore 0 (tidak stress). Hasil didapatkan pada klien I dan klien II terjadi penurunan tingkat stress terhadap tekanan darah dan kecemasan.Masalah ansietas pada klien I dan klien II teratasi.

\section{Kesimpulan}

Kesimpulan dari studi kasus ini adalah adanya pengaruh yang bermakna penurunan skore stress antara sebelum dan setelah diberikan intervensi kombinasi pijat punggung dan dzikir. Penurunan stress yang terjadi merpakan efek positif dari kombinasi relaksasi tersebut. Pada langkah selanjutnyan diharapkan penurunan stress akan mempengaruhi pula terhadap penurunan stress akan tekanan darah pada penderita hipertensi. Bagi ilmu keperawatan, dengan adanya hasil penelitian ini dapat dijadikan referensi tambahan bahwa selain terapi medis ada intervensi mandiri keperawatan yaitu kombinasi pijatan punggung dzikir dalam menangani pasien hipertensi. Dengan mengaplikasikan kedalam suatu bentuk protap, Standar Prosedur Operasional dan menjadi salah satu materi yang diajarkan pada skills lab pendidikan keperawatan.

\section{Saran}

Saran yang penulis berikan terkait dengan masalah tingkat stress terhadap penderita hipertensi yaitu : 1. Bagi klien dapat mengontrol hipertensi dengan kecemasan dengan menggunakan terapi pijat punggung dan dzikir. 2. Keluarga hendaknya memberikan dukungan dan ikut serta membantu klien dalam proses penyembuhan klien dengan tingkat stress pada penderita hipertensi. 3.Mahasiswa yang sedang praktik hendaknya lebih memberikan motivasi dan dukungan agar klien dengan tingkat stress pada hipertensi dapat teratasi, karena klien dengan tingkat stress pada hipertensi dapat mengalami tanda-tanda dan gejala, cemas, stress, gelisah, pusing, lemas dan khawatir terhadap penyakitnya, oleh karena itu diberikan non-farmakologi 


\section{Prosiding Seminar Nasional Kesehatan Lembaga Penelitian dan Pengabdian Masyarakat Universitas Muhammadiyah Pekajangan Pekalongan}

relaksasi kombinasi pijat punggung dan dzikir. 4. Bagi institusi diharapkan Karya Tulis Ilmiah ini dapat digunakan sebagai bahan rujuan studi kasus berikutnya.

\section{Referensi}

[1] Dinas Kesehatan Provinsi Jawa Tengah. 2015. Profil Kesehatan Jawa Tengah. Semarang.

[2] Elani Andreou, Evangelos C, Alexopouious, Christos Lionis, Liza Varvogoli, Charalam bos Chardellis, George I. Chrousus \&christina Darviri. 2011. Perceived Stress Scale : Reliability and validity study in Greece. Int. J. Environ. Res. Public Healt, 8 ,3287-3298.

[3] Fatoni, A. 2020. Intergrasi Zikir dan Pikir Dasar Pengembangan Pendidikan Islam. Nusa Tenggara Barat : Forum Pemada Aswaja.

[4] Herdman, T. Heather \& Shigemi Kamitsuru. 2018. Nanda-1 Diagnosis Keperawatan

Definisi dan Klasifikasi 2018-2020.Jakarta : EGC.

[5] Hanif, Yulinggaaa, dk.2019. Cara cepat kuasai Massage Kebugaran Berbasis Aplikasi Android. Kediri : CV. Kasih Inovasi Teknologi.

[6] Keliat, Anna, Budi. 2019. Asuhan Keperawatan Jiwa 2019. Jakarta : EGC. Persatuan Perawat Nasional Indonesia (PPNI). 2016. Standar Diagnosis Keperawatan Indonsia Definisi dan Indikator Diagnosis. Jakarta : DPP PPNI.

[7] Pemerintahan Kabupaten Batang, Dinas Kesehatan. 2017. Profil Kesehatan Kabupaten Batang.

[8] Priyoto. 2014. Konsep Manajemen Stress. Yogyakarta : Nuhan Medika.

[9] Rudi Haryono. dkk. 2016. "Pengaruh Kombinasi Pijat Punggung dan Dzikir Tterhadap Tingkat Stress Pada Penderita Hipertensi ". Jurnal Keperawatan Notokusumo.

[10] Tewa, Berhard, dkk. 2017. Perilaku Organisai. Bandung : CV.Patra Media Grafindo.

[11] Tim Bumi Medika. 2017. Berdamai dengan Hipertensi. Jakarta : Bumi Medika.

[12] Triyanto, Endang. 2014. Pelayanan Keperawatan bagi penderita Hipertensi Secara Terpadu. Yogyakarta : Graha IImu. Wuryaningsih, Emi Wuri, dkk. 2018. Keperawatan Kesehatan Jiwa I. Jember : UPT Percetakan \& Penerbitan Universitas Jember.

[13] Yosep, Iyus \& Titin Sutini. 2017. Buku Ajar Keperawatan Jiwa. Bandung : PT Refika Aditama. 